Personalidade Acadêmica Homenageada:

Augustus B. Cochran III (Agnes Scott College)

\title{
A CONSTRUÇÃO DA IMAGEM DE HERÓI DO TRANSGRESSOR DA NORMA JURÍDICA
}

\section{THE CONSTRUCTION OF THE LEGAL STANDARD TRANSGRESSOR HERO IMAGE}

\section{JHONATHANN WILKER SILVA}

Graduando em Direito na modalidade Integral - Escola Superior Dom Helder Câmara. Belo Horizonte - MG. E-mail: jhonathannwilker@gmail.com.

\section{MATEUS VICENTE VIEIRA ARANHA}

Graduando em Direito na modalidade Integral - Escola Superior Dom Helder Câmara. Belo Horizonte - MG. E-mail: mateusaranha14g5@gmail.com.

CAIO AUGUSTO SOUZA LARA

Mestre e Doutor em Direito pela Faculdade de Direito da Universidade Federal de Minas Gerais - UFMG. Professor da Escola Superior Dom Helder Câmara. Pesquisador Associado ao Programa RECAJ-UFMG - Acesso à Justiça e Solução de Conflitos. Secretário de Comunicação do Conselho Nacional de Pesquisa e Pósgraduação em Direito - CONPEDI. Belo Horizonte-MG. E-mail: caiolarabh@yahoo.com.br.

\section{RESUMO}

O problema objeto da investigação científica proposta é: por que traficantes, notórios violadores das normas jurídico-penais, são vistos como heróis nas favelas brasileiras e mantêm sua popularidade entre os moradores? É possível afirmar inicialmente que esses traficantes garantem o império da lei e o direito no local onde 


\section{Personalidade Acadêmica Homenageada:}

\section{Augustus B. Cochran III (Agnes Scott College)}

detêm o monopólio da violência, e mantêm sua popularidade entre os moradores por meio da assistência social. Vale ressaltar também que devido à falta de um estado mínimo, de uma instituição que garanta o cumprimento de contratos e os direitos de propriedade, esses "heróis" são vistos como supostos salvadores do povo. O temaproblema da pesquisa que se pretende desenvolver é a construção da imagem dos heróis nas favelas brasileiras. Tudo começa com um problema fundamental: a falta de representatividade do cidadão da favela fora dela. Acontece que nem sempre o governo civil desempenha ou aceita desempenhar o papel de garantidor de visibilidade para os moradores das favelas. Diante disso os moradores dessas periferias podem vir a se questionarem se eles não querem que detenham liberdade para planejar e tentar implementar suas ideias, sem a interferência de ninguém. Viver a sensação de não pertencimento com o território e com outros indivíduos faz com que os sujeitos vivam, queiram ou não, à margem da sociedade, como turistas. Quando não vivem dessa forma, estão condicionados a algo ainda pior: a condição de "vagabundos". Em outras palavras, imputa-se que o "favelado" é um mero marginal e não tem as habilidades que Ihe permita participar ativamente da sociedade, sendo condicionado à preconceitos e estereótipos negativos. É culturalmente pobre e marginalizado, o que não permite que seja tratado de forma normal. É a partir desse momento que entram os heróis, que garantem o império da lei, segurança e o direito no local onde detém o monopólio da violência, e mantém sua popularidade entre os moradores por meio da assistência social. $O$ objetivo geral do trabalho é analisar o fenômeno de "heroísmo" que é causado nas favelas brasileiras, geralmente defendido pela maioria de seus moradores. É necessário também examinar a influência totalitária que impacta na formação da mentalidade política e comunitária e compreensão da dinâmica das relações de poder na sociedade. Em suma, todas as normas do morro estão sujeitas a ditadura do herói, onde para a comunidade o inimigo comum é a polícia. Sem embargo, geralmente a polícia ou um grupo competitivo está situado em uma parte da sociedade em que se vê em constante conflito de imposição da lei e da justiça criminal, na qual as relações humanas são transformadas em mercadorias. A pesquisa que se propõe pertence à vertente metodológica jurídico-sociológica. No tocante ao tipo de 


\section{Personalidade Acadêmica Homenageada:}

\section{Augustus B. Cochran III (Agnes Scott College)}

investigação, foi escolhido, na classificação de Witker (1985) e Gustin (2010), o tipo jurídico-projetivo. O raciocínio desenvolvido na pesquisa será predominantemente dialético. De acordo com a técnica de análise de conteúdo, afirma-se que se trata de uma pesquisa teórica, o que será possível a partir da análise de conteúdo dos textos doutrinários, normas e demais dados colhidos na pesquisa. A partir do exposto conclui-se preliminarmente que nas favelas brasileiras faz-se valer da representatividade do "dono do morro", o que abre margem para a população da comunidade o ter como seu herói. Com isso a popularidade se faz como presente na maioria desses criminosos, que são vistos como salvadores. A partir desse momento o Estado acaba por enfrentar dificuldades para combater esses chefes, já que uma grande parte da população os defende e vêm o governo como inimigo. Então é construída uma desconfiança exacerbada em que o traficante ocupa o espaço que o Estado deixou vazio.

PALAVRA-CHAVE: Favelas Brasileiras; Herói da Favela; Donos do Morro; Norma Penal; Violação.

\section{REFERÊNCIAS}

CIDADE dos homens. Direção de Fernando Meirelles. Rio de janeiro: Rede Globo Flmes, 2002. (30 minutos)

CONEXÃO Repórter (28/08/16) - O Senhor do Tráfico - Completo. Youtube: SBT, 2016. Disponível em: https://www.youtube.com/watch?v=TWciz8eSd9w. Acesso em: 13 abr. 2019.

COSTA, Carlos. A favela não elege seus vilões. Vlex, 10 dez. 2017. Disponível em: https://2019.vlex.com/\#search/jurisdiction:BR/favela/WW/vid/698629885. Acesso em: 4 abr. 2019.

GUSTIN, Miracy Barbosa de Sousa; DIAS, Maria Tereza Fonseca. (Re)pensando a pesquisa jurídica: teoria e prática. 3ª . ed. Belo Horizonte: Del Rey, 2010.

HOBBES, Thomas. Leviatã. Ed. Martin Claret, São Paulo, 2006. 
Personalidade Acadêmica Homenageada:

Augustus B. Cochran III (Agnes Scott College)

JACQUES, Paola Berenstein. Estética da Ginga: a arquitetura das favelas através da obra de Hélio Oiticica. Rio de Janeiro: Casa da Palavra, 2007.

LINS, Paulo. Cidade de Deus. Rio de Janeiro: Planeta, 1997.

MIKALOVSKI, Algalcir. Os impactos das ações afirmativas na Segurança Pública. Revista Jurídica Unicuritiba. Curitiba, v.27, n.11, 2011. Disponível em: http://revista.unicuritiba.edu.br/index.php/RevJur/article/view/208. Acesso em: 20/05/2019.

WITKER, Jorge. Como elaborar una tesis en derecho: pautas metodológicas y técnicas para el estudiante o investigador del derecho. Madrid: Civitas, 1985. 